\title{
Timing Long Horizon Predictability: Investment Implications
}

\author{
Dimitrios Tsoukalas, (Email: tsoukala@ calumet.purdue.edu), Purdue University - Calumet \\ Musa Darayseh, (Email: aldara@calumet.purdue.edu), Purdue University - Calumet \\ Radian Abuizam, Purdue University - Calumet
}

\begin{abstract}
The analysis in this paper is twofold: a) we use the Vector Autoregressive (VAR) methodology to briefly study predictability of bond and stock returns, and b) we investigate the efficiency of stock and bond markets by exploring a buy and sell strategy made up of a hypothetical portfolio which consists of bonds and stocks. Our strategy indicates that unexploited profit opportunities exist in the U.S. security markets. The trading strategy used to identify profitability is based on return predictability. More specifically, we estimate risk-adjusted cumulative twelve-month and quarterly compounded returns on the Dow Jones Industrial Average and the 30-year U.S. Treasury bonds using a state of the art forecasting model. We construct our portfolio which consists of bonds and stocks based on the highest forecast given by the model as follows. Buy stocks when the forecast shows returns are higher in the stock market. Switch your portfolio into bonds every time the forecast model shows higher returns in the bond market.
\end{abstract}

\section{INTRODUCTION}

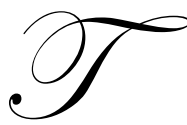

he motivation for writing this paper relies on the extensive work which has shown that long-term bond returns are predictable using the slope of the term structure of interest rates ${ }^{1}$, and the dramatic resurgence of academic interest in the predictability of stock returns based on their past history ${ }^{2}$. At the same time, the term structure has considerable long-horizon forecasting power for long-horizon nominal interest rate movements and for inflation rates ${ }^{3}$.

The analysis in this paper is twofold: a) we use the Vector Autoregressive (VAR) methodology to briefly study predictability of bond and stock returns, and $b$ ) we investigate the efficiency of stock and bond markets ${ }^{4}$ by exploring a buy and sell strategy made up of a hypothetical portfolio which consists of bonds and stocks. Our strategy indicates that unexploited profit opportunities exist in the U.S. security markets. The paper is organized as follows: Section II briefly describes the variables used in the VAR model, the data for the bond market and Dow Jones Industrial Average and explains Granger causality results. Section III constructs and presents a hypothetical portfolio from bonds and stocks in the U.S. market. These results indicate that our portfolio "beats" the Dow Jones Industrial Average for the period 1979 to 1997.

\section{VARIABLES IN THE SYSTEM, DATA ANALYSIS AND DEFINITIONS}

We employ a two-variable unrestricted Vector Autoregressive (VAR) model in each market. The basic variables we use are returns and the spread (SPR), the difference between short and long term interest rates), for the bond market. The return on a long-term bond held from $t$ to $t+1$ can be written as:

\footnotetext{
${ }^{1}$ See Campbell and Shiller (1991), Fama (1984), Shiller, Campbell and Schoenholtz (1983), and Campbell and Ammer (1993).

${ }^{2}$ See Fama and French (1988), Lo and MacKinley (1988), Poterba and Summers (1988)

${ }^{3}$ See Campbell and Shiller (1987), Fama and Bliss (1987), Mishkin (1991, 1992) and Frankel and Lown (1994).

${ }^{4}$ See Fama(1970, 1991).
} 
$\mathrm{H}_{\mathrm{t}}=\mathrm{C}+\mathrm{P}_{\mathrm{t}+1}-\mathrm{P}_{\mathrm{t}} / \mathrm{P}_{\mathrm{t}}$

where $\mathrm{H}_{\mathrm{t}}$ is the rate of long term government bonds with ten or twenty-years to maturity ${ }^{5}$, between period $t$ to $t+1$. $P_{t}$ is the price of the bond at time $t$

$\mathrm{P}_{t+1}$ is the price of the bond at price $t+1$

$\mathrm{C}$ is the coupon payment

A convenient way to rewrite the above formula is to recognize that it can be split up into two separate terms. The first is the current yield, $i_{c}$ (the coupon payment over the purchase price):

$\mathrm{C} / \mathrm{P}_{\mathrm{t}}=\mathrm{i}_{\mathrm{c}}$

The second term is the rate of capital gains, or the change in the bond's price relative to the initial purchase price:

$P_{t+1}-P_{t} / P_{t}=g$

where $\mathrm{g}$ is the rate of capital gains

Equation (1) can then be written as

$\mathrm{H}_{\mathrm{t}}=\mathrm{i}_{\mathrm{c}}+\mathrm{g}$

which shows that the return on a bond is the current yield $\left(\mathrm{i}_{\mathrm{c}}\right)$ plus the rate of capital gains. If $\mathrm{H}_{\mathrm{t}}$ is the holding period return on a consol between period $t$ and $t+1$, the investor who holds the instrument for one period will receive both the coupon payment $(\mathrm{C})$ and the capital gain $\left(\mathrm{P}_{\mathrm{t}}-\mathrm{P}_{\mathrm{t}-1}\right)$.

The above rewritten formula illustrates that even for a bond for which the current yield, $\mathrm{i}_{\mathrm{c}}$, is an accurate measure of the yield to maturity, the return can differ substantially from the interest rate. This will occur if there are sizable fluctuations in the price of the bond that produce substantial capital gains or losses. That is, if the long term interest rate remains unchanged between $\mathrm{t}-1$ and $\mathrm{t}$, the holding return equals the yield. If the long-term rate rises, the investor suffers a capital loss on the bond, and the holding return is less than the yield. On the other hand, if the longterm rate falls, the bond holder realizes a capital gain and the holding return exceeds the yield.

For the spread (SPR) we use the difference between long term over short-term interest rates $\mathrm{LR}_{\mathrm{t}}-\mathrm{SR}_{\mathrm{t}}$, where $\mathrm{LR}_{\mathrm{t}}$ is the rate of long term government bonds with ten or twenty-years to maturity, and $\mathrm{SR}_{\mathrm{t}}$ is the one period yield of the three-month Treasury Bill rate. These rates were obtained from the Citibase data bank. The sample period starts from $1 / 1955$ to $12 / 1997$.

The two variable VAR system of the stock market includes real stock returns, and dividend-price ratios. We use the monthly closing prices and the corresponding dividend yield from 12/1955 to 12/1997 for the DJI average. The stock prices were taken from the Citibase data bank while, the dividend yield was obtained from Barron's magazine. The monthly stock market index was transformed to monthly rates of return ${ }^{6}$. The use of monthly returns eliminates nonstationarity in the original stock market prices. To construct the formula for nominal stock returns we use the capital gain returns from the end of month values of the Dow Jones Industrial Average and we add the corresponding dividend yields. Real returns are nominal returns adjusted for the inflation rate. The formula of real stock returns is defined as follows:

$\mathrm{RS}_{\mathrm{t}}=\left(\mathrm{S}_{\mathrm{t}}-\mathrm{S}_{\mathrm{t}-1}+\mathrm{D}_{\mathrm{t}}\right) /\left(\mathrm{S}_{\mathrm{t}-1}\right)$

\footnotetext{
${ }^{5}$ For simplicity we assume that the bond is a consol, an infinitely lived security paying a fixed amount each period.

${ }^{6}$ To take account for possible seasonalities in dividends the tests have also been run with seasonally adjusted data.
} 
where $\mathrm{RS}_{\mathrm{t}}$ is stock returns at time $\mathrm{t}$,

$\mathrm{S}_{\mathrm{t}}$ is the stock price index at time $\mathrm{t}$,

$\mathrm{S}_{\mathrm{t}-1}$ is the lagged stock price at time $\mathrm{t}-1$ and

$\mathrm{D}_{\mathrm{t}}$ is the dividend series $\mathrm{t}$.

For the dividend-price ratio we use two definitions ${ }^{7}$ : a) $d_{t}=D_{t-1} / P_{t}$ where $D_{t-1}$ is the dividend of last period, to ensure that it is known at the start of month $t$, and $\mathrm{P}_{t}$ is the price of the stock at time $t$; b) $d_{t}=D_{t} / P_{t}$ which indicates dividend at time $t$ dividend by the stock price at time . $^{8}$

\section{III.1.2 GRANGER CAUSALITY}

The primary interest of this paper is causality from the spread to holding period returns on long term bonds $(\mathrm{H})$. The VAR model uses as right-hand side variables lagged values of bond returns (H) and the spread (SPR) and/or stock returns (RS) and the dividend-price ratio (D/P). Significant Granger F values would indicate that there are lagged relationships between holding period returns and the spread and/or between stock returns and the dividend-price ratio. In other words, holding period returns in the bond market can be predicated by changes in the spread, while in the stock market returns can be predicted by changes in the dividend-price ratio.

We estimate the reduced form VAR equation by equation in an OLS regression described as: $X_{t}=a+S_{i=1}^{k}$ $\mathrm{a}_{\mathrm{i}} \mathrm{H}_{\mathrm{t}-}$

${ }_{k}+S_{i=1}^{k} b_{i} S P R_{t-k}+e_{t}$

where $X_{t}=H$ or SPR. For the DJI, $X=$ real stock returns (defined as in the text) or dividend-price ratio. In order to test for Granger causality we test the null hypothesis that $a_{i}$ and $b_{i}$ are jointly significantly different from zero.

The hypothesis for testing the predictability in bond returns is that the spread (Long minus Short) should not forecast the holding return (the return of long term instrument). In other words, the difference between long and short rates should not reveal any profit opportunities for holding long instruments over short instruments or vice-versa for a period of time. It is the important implication of the expectations theory that realized rates of return for bonds of different maturities over a holding period will be the same. The implication of this is that if the holding period returns is regressed on the lagged holding returns and lagged spread the coefficients should be zero. That is, no causality should run from the spread to the holding return. This hypothesis has been tested by Shiller (1978). Similar hypotheses have been tested by Mankiw (1986), Andrianacos (1989).

According to the proposition of nonpredictability there should be no significant lag effects from the dividendprice ratio to real stock returns.

Table II presents Granger-causality test results for the full period $1 / 1955$ to $12 / 1997^{9}$. As the table indicates stocks and bond returns are predictable with an $\mathrm{F}=17.06$ with significance score of 1.00 for stocks and $\mathrm{F}=3.700$ with significance $\mathrm{P}=0.999$ for bonds, respectively. In addition, one-way Granger-causality evidence from bond returns to short-term interest rates was found, from H to SPR: 6.388 (1.00).

\section{TRADING STRATEGY}

Trading strategies that apparently "beat the market" date back to the inception of trading in financial assets. A number of practitioners and academics in the pre-market-efficiency era (pre-1960s) believed that predictable patterns in

\footnotetext{
${ }^{7}$ The reason we use two definitions is that these have been used in the literature. Fama and French used d=D/P, while Campbell and Shiller (1988), Campbell (1991), Campbell and Ammer (1993) used d=LD/P. Although the difference in these formulas is insignificant, we want to compare our results with both formulas. We report the results of $d=D / P$.

${ }^{8}$ Stationarity tests are shown in Table I in Appendix I.

${ }^{9}$ Monthly results are available upon request.
} 
stock returns could lead to "abnormal" profits to trading strategies. In recent years, there has been a dramatic resurgence of academic interest in the predictability of asset returns based on their past history. More, significantly, a growing number of researchers argue that the time-series patterns in returns can be utilized to consistently "outperform" the market. ${ }^{10}$

The trading strategy we develop here is based on the empirical methodology we use to uncover return predictability. In other words, our trading strategy is based on the information contained in past returns of bonds and stocks from $1 / 1955$ to $12 / 1997$. Thus, the strategy used to identify profitability is based on return predictability. Specifically, we estimate cumulative twelve-month and quarterly compounded returns on the Dow Jones Industrial Average and the 30-year U.S. Treasury bonds using a state of the art forecasting model. ${ }^{11}$

We construct our portfolio which consists of bonds and stocks based on the highest forecast given by the model as follows. Buy stocks when the forecast shows returns are higher in the stock market. Switch your portfolio into bonds every time the forecast model shows higher returns in the bond market. As table III shows, in the first quarter of 1997 we invest in stocks because our forecast is $2.5 \%$ versus $.1 .61 \%$ for bonds; in the next quarter we also buy stocks, the forecasts are $3.06 \%$ for the DJI versus $1.69 \%$ for bonds. We continue rebalancing our portfolio quarter after quarter as the table indicates. Each year bonds are held, the yield is the nominal monthly interest rate on the three-month T-bills minus the actual inflation rate, and this and all dividends are reinvested. In table IV we compare actual cumulative compounded returns of our portfolio with actual compounded returns of the DJI average from 1979 to 1997. Our analysis leads to some interesting findings. First, we find, that for the period of 1979 to 1997 our portfolio "beats" the Dow Jones Industrial in cumulative compounded returns. Specifically, if we had invested at the beginning of $1979 \$ 100$ in the DJI, by the end of 1997 we would have accumulate $\$ 452.83$ versus $\$ 802.8$ generated by our portfolio. The returns of our portfolio were sufficiently large to compensate for the fact that bond, which on average had a lower yield than equities, had to be held when there were no profitable opportunities available on the stock market. From the returns columns on table III we see that our forecast model correctly predicted the crash of equities in the fourth quarter of 1987. In that quarter our forecast was $-1.89 \%$ in the returns of the DGJ versus $2.37 \%$ in bonds which led us to switch our portfolio to bonds at the beginning of the fourth quarter of 1987 avoiding thus catastrophic losses. The DGI fell by $25.43 \%$ in only a few hours. Our rule also predicted the small crash of the fourth quarter of 1989 , and the decline of the DGJ in October of 1997. Although, the model could not measure the magnitude of the decline in stock or bond prices it sent signals to switch our portfolio into bond markets, avoiding the losses in the equity markets. The returns of our portfolio were sufficiently large to compensate for the fact that bond, which on average had a lower yield than equities, had to be held when there were no profitable opportunities available on the stock market. Our returns also, are large to also compensate for trading commissions.

\section{APPENDIX I.1}

TABLE I

A. Stationarity tests for Bonds

\begin{tabular}{||c|c|c|c|c|c|c||}
\hline \hline VAR. & $\mathrm{K}$ & $\mathrm{DF}(\mathrm{t})$ & $\mathrm{PP}(\mathrm{t})$ & $\mathrm{K}$ & $\mathrm{ADF}(\mathrm{t})$ & $\mathrm{APP}(\mathrm{t})$ \\
\hline IR & 0 & -2.13 & -2.13 & 1 & -2.75 & -2.37 \\
\hline LR & 0 & -1.56 & -1.56 & 1 & -1.71 & -1.63 \\
\hline H & 0 & $-16.47^{++}$ & $-16.51^{++}$ & 1 & $-16.58^{++}$ & $-16.64^{++}$ \\
\hline SPR & 0 & $-3.19^{+}$ & $-3.20^{+}$ & 1 & $-4.04^{+}$ & $-3.55^{+}$ \\
\hline DSR & 0 & $-16.03^{++}$ & $-16.07^{++}$ & 1 & $-15.36^{++}$ & $-16.18^{++}$ \\
\hline
\end{tabular}

B. Stationarity tests for Dow Jones Industrial Average

\begin{tabular}{||c|c|c|c|c|c|c||}
\hline VAR. & $\mathrm{K}$ & $\mathrm{DF}(\mathrm{t})$ & $\mathrm{PP}(\mathrm{t})$ & $\mathrm{K}$ & $\mathrm{ADF}(\mathrm{t})$ & $\mathrm{APP}(\mathrm{t})$ \\
\hline SP & 0 & 3.04 & -2.00 & 1 & 2.52 & 1.68 \\
\hline $\mathrm{DIV}$ & 0 & -.499 & -.130 & 1 & -.130 & .112 \\
\hline RSR & 0 & $-16.56^{++}$ & $-16.59^{++}$ & 1 & $-13.24^{++}$ & $-16.60^{++}$ \\
\hline $\mathrm{D} / \mathrm{P}$ & 0 & -1.30 & $-1.31^{+}$ & 1 & -3.45 & -1.81
\end{tabular}

\footnotetext{
${ }^{10}$ See Alexander (1967) and Conrad and Kaul (1995), Bassembinder and Chan (1995).

${ }^{11}$ We use the statistical packages of RATS and B34S for this study.
} 


\begin{tabular}{||l|l|l|l|l|l|l||}
\hline$(\mathrm{D} / \mathrm{P})_{\mathrm{t}-1}$ & 0 & $-8.98^{++}$ & $-9.00^{++}$ & 1 & $-10.53^{++}$ & $-9.51^{++}$ \\
\hline
\end{tabular}

Notes: 1). The OLS equation is $\mathrm{y}_{\mathrm{t}}=\mathrm{a}+\mathrm{by}_{\mathrm{t}-1}+\mathrm{u}_{\mathrm{t}}$

2). $\mathrm{DF}(\mathrm{t})$ is the Dickey-Fuller $\mathrm{t}$-ratio for $\mathrm{b}=0$ with $\mathrm{k}=0$ (no lags in the equation). $\mathrm{PP}(\mathrm{t})$ is the Phillips -Perron $\mathrm{t}$-test statistic for $\mathrm{b}$. $\mathrm{ADF}(\mathrm{t})$ and APP $(\mathrm{t})$ are the augmented tests where one lag is added to the equation.

${ }^{++}$significant at the $1 \%$ level. Critical value $=-3.46$

${ }^{+}$significant at the $5 \%$ level. Critical value $=-2.88$

* significant at the $10 \%$ level. Critical value $=-2.57$

If the t-ratio is not significant the null that $\mathrm{y}$ is not a unit root process cannot be rejected.

3 ). $\mathrm{IR}=$ short-term interest rates, $\mathrm{LR}=$ long-term bonds, DST $=1$ st difference in short-term interest rates, $\mathrm{H}=$ holding returns of long-term bonds.

4). $\mathrm{SP}=$ Stock Price, $\mathrm{DIV}=$ dividend payments, $\mathrm{RSR}=$ real stock returns, $\mathrm{D} / \mathrm{P}=$ Dividend-Price ratio, $(\mathrm{D} / \mathrm{P})_{\mathrm{t}-1}=\mathrm{Lagged}$ dividendprice ratio.

TABLE II

A. GRANGER CAUSALITY TESTS FOR BOND MARKETS

\begin{tabular}{|c|c|c|c|c|}
\hline Variables & $\mathrm{F}_{11}$ & $\mathrm{~F}_{12}$ & $\mathrm{~F}_{21}$ & $\mathrm{~F}_{22}$ \\
\hline $\begin{array}{l}\text { Bond returns } \\
\text { (h) }\end{array}$ & $\begin{array}{c}7.72 \\
(1.00)\end{array}$ & $\begin{array}{l}3.700 \\
(.999)\end{array}$ & $\begin{array}{l}6.388 \\
(1.00)\end{array}$ & $\begin{array}{l}379.96 \\
(1.00)\end{array}$ \\
\hline
\end{tabular}

B. GRANGER CAUSALITY TESTS FOR DOW JONES INDUSTRIAL AVERAGE

\begin{tabular}{|c|c|c|c|c||}
\hline \hline Variables & $\mathrm{F}_{11}$ & $\mathrm{~F}_{12}$ & $\mathrm{~F}_{21}$ & $\mathrm{~F}_{22}$ \\
\hline Stock returns & 3.565 & $\mathbf{1 7 . 8 0 6}$ & 1.682 & 56.65 \\
$(\mathrm{sr})$ & $(.999)$ & $\mathbf{( 1 . 0 0 )}$ & $(.909)$ & $(1.00)$ \\
\hline
\end{tabular}

Notes:1) F-value for null hypothesis. Significant level in brackets. A significant F-value is evidence of the Granger-causality. The Granger test statistic is distributed as $\mathrm{F}(\mathrm{n} 1, \mathrm{n} 2)$ where $\mathrm{n} 1=12$ or the number of lags and $\mathrm{n} 2=515$ - the number of observations or the number of the right hand side variables. The value of the statistic is ((RSS-USS)/USS)*(n2/n1) where RSS and USS is the restricted and unrestricted sum of squares. 2) Bold indicates Granger-causality from short-term interest rates to bond returns.

TABLE III

QUARTERLY COMPOUNDED RETURNS FOR DJI AND THREE MONTH T-BILLS

\begin{tabular}{|c|c|c|c|c|}
\hline & \multicolumn{2}{|c|}{ DOW JONES INDUSTRIAL AV. } & \multicolumn{2}{|c|}{ BONDS } \\
\hline $\begin{array}{c}\text { Year-QTR } \\
1997 \\
\end{array}$ & $\begin{array}{c}\text { Actual Compound } \\
\text { Returns } \\
\end{array}$ & $\begin{array}{c}\text { Forecast Compound } \\
\text { Returns } \\
\end{array}$ & $\begin{array}{c}\text { Actual Compound } \\
\text { Returns }\end{array}$ & $\begin{array}{c}\text { Forecast Compound } \\
\text { Returns }\end{array}$ \\
\hline 1 & $1.016-1=1.6 \%$ & $1.025-1=2.5 \%$ & $1.010-1=1.0 \%$ & $1.0161-1=1.61 \%$ \\
\hline \multirow[t]{2}{*}{2} & $1.169-1=16.9 \%$ & $1.0306-1=3.06 \%$ & $1.069-1=6.9 \%$ & $1.0169-1=1.69 \%$ \\
\hline & $1.033-1=3.3 \%$ & $1.0369-1=3.69 \%$ & $1.0156-1=1.56 \%$ & $1.0102-1=1.02 \%$ \\
\hline 4 & $.998-1=-.12 \%$ & $1.0051-1=.51 \%$ & $1.0148-1=1.48 \%$ & $1.015-1=1.5 \%$ \\
\hline \multicolumn{5}{|l|}{1996} \\
\hline 1 & $1.087-1=8.67 \%$ & $1.0228-1=2.28 \%$ & $1.014-1=1.4 \%$ & $1.014-1=1.4 \%$ \\
\hline 2 & $1.0116-1=1.16 \%$ & $1.0243-1=2.43 \%$ & $1.0168-1=1.68 \%$ & $1.016-1=1.6 \%$ \\
\hline 3 & $1.0388-1=3.83 \%$ & $1.00078-1=.078 \%$ & $1.017-1=1.7 \%$ & $1.017-1=1.7 \%$ \\
\hline 4 & $1.096-1=9.6 \%$ & $1.007-1=.7 \%$ & $1.0159-1=1.59 \%$ & $1.016-1=1.6 \%$ \\
\hline \multicolumn{5}{|l|}{1995} \\
\hline 1 & $1.0787-1=7.87 \%$ & $.999-1=.10 \%$ & $1.018-1=1.8 \%$ & $1.0192-1=1.92 \%$ \\
\hline 2 & $1.0954-1=9.54 \%$ & $1.0038-1=.38 \%$ & $1.016-1=1.6 \%$ & $1.0173-1=1.73 \%$ \\
\hline 3 & $1.0521-1=5.21 \%$ & $1.0235-1=2.35 \%$ & $1.0158-1=1.58 \%$ & $1.0159-1=1.59 \%$ \\
\hline 4 & $1.0729-1=7.29 \%$ & $1.01183-1=1.83 \%$ & $1.0148-1=1.48 \%$ & $1.0151-1=1.51 \%$ \\
\hline \multicolumn{5}{|l|}{1994} \\
\hline 1 & $1.147-1=14.7 \%$ & $1.0043-1=.43 \%$ & $1.0152-1=1.52 \%$ & $1.014-1=1.4 \%$ \\
\hline 2 & $.9981-1=-.16 \%$ & $1.00715-1=.715 \%$ & $1.017-1=1.7 \%$ & $1.0173-1=1.73 \%$ \\
\hline
\end{tabular}




\begin{tabular}{|c|c|c|c|c|}
\hline 3 & $1.0582-1=5.82 \%$ & $.990-1=-.94$ & $1.0184-1=1.84 \%$ & $1.018-1=1.8 \%$ \\
\hline 4 & $1.0019-1=.19 \%$ & $.9851-1=-1.49 \%$ & $1.020-1=2.0 \%$ & $1.0197-1=1.97 \%$ \\
\hline \multicolumn{5}{|c|}{1993} \\
\hline 1 & $1.042-1=4.22 \%$ & $.986-1=-1.3$ & $1.015-1=1.5 \%$ & $1.0158-1=1.58 \%$ \\
\hline 2 & $1.091-1=1.91 \%$ & $1.0188-1=1.88 \%$ & $1.015-1=1.5 \%$ & $1.0149-1=1.49 \%$ \\
\hline 3 & $1.130-1=1.3 \%$ & $1.0168-1=1.69 \%$ & $1.014-1=1.4 \%$ & $1.0144-1=1.44 \%$ \\
\hline 4 & $1.0586-1=5.86 \%$ & $1.0162-1=1.63 \%$ & $1.014-1=1.4 \%$ & $1.015-1=1.5 \%$ \\
\hline \multicolumn{5}{|c|}{1992} \\
\hline 1 & $1.0208-1=2.08 \%$ & $1.0040-1=.40 \%$ & $1.019369-1=1.8369 \%$ & $1.01796-1=1.796 \%$ \\
\hline 2 & $1.02886-1=2.88 \%$ & $1.0268-1=2.68 \%$ & $.01855-1=1.855 \%$ & $1.01864-1=1.864 \%$ \\
\hline 3 & $.9869-1=-1.31 \%$ & $.9715-1=-2.85$ & $1.01663-1=1.663 \%$ & $1.01714-1=1.714 \%$ \\
\hline 4 & $1.00514-1=.514 \%$ & $.9737-1=-263 \%$ & $1.0169-1=1.169 \%$ & $1.01669-1=1.669 \%$ \\
\hline \multicolumn{5}{|c|}{1991} \\
\hline 1 & $1.1062-1=10.62 \%$ & $1.0040-1=.4 \%$ & $1.02018-1=2.018 \%$ & $1.02015-1=2.015 \%$ \\
\hline 2 & $.9976-1=-.24 \%$ & $1.07504-1=7.504 \%$ & $1.02046-1=2.046 \%$ & $1.02028-1=2.028 \%$ \\
\hline 3 & $1.03603-1=3.603 \%$ & $1.0655-1=6.555 \%$ & $1.01998-1=1.998 \%$ & $1.0204-1=2.04 \%$ \\
\hline 4 & $1.0517-1=5.217 \%$ & $1.01933-1=1.933 \%$ & $1.01848-1=1.848 \%$ & $.01891-1=1.891 \%$ \\
\hline \multicolumn{5}{|l|}{1990} \\
\hline 1 & $.9814-1=-1.86$ & $.9391-1=-6.09 \%$ & $1.021206-1=2.120 \%$ & $1.02074-1=2.074 \%$ \\
\hline 2 & $1.0643-1=6.43 \%$ & $.9603-1=-3.97 \%$ & $1.02185-1=2.185 \%$ & $1.021844-1=2.1844 \%$ \\
\hline 3 & $.8393-1=-16.06 \%$ & $1.00216-1=.216 \%$ & $1.021916-1=2.1916 \%$ & $1.02163-1=2.163 \%$ \\
\hline 4 & $1.0752-1=7.52 \%$ & $1.01064-1=1.064 \%$ & $1.02114-1=2.114 \%$ & $1.02162-1=2.162 \%$ \\
\hline \multicolumn{5}{|l|}{1989} \\
\hline 1 & $1.0557-1=5.57 \%$ & $.9972-1=-.28 \%$ & $1.023193-1=2.319 \%$ & $1.0229-1=2.29 \%$ \\
\hline 2 & $1.0875-1=8.75 \%$ & $1.0179-1=1.79 \%$ & $1.02209-1=2.209 \%$ & $1.02286-1=2.286 \%$ \\
\hline 3 & $1.0809-1=8.09 \%$ & $1.00837-1=.837 \%$ & $1.02043-1=2.043 \%$ & $1.0205-1=2.05 \%$ \\
\hline 4 & $1.0135-1=1.35 \%$ & $.9518-1=-4.82 \%$ & $1.019896-1=1.9896 \%$ & $1.02008-1=2.008 \%$ \\
\hline \multicolumn{5}{|c|}{1988} \\
\hline 1 & $1.0698-1=6.98 \%$ & $.9285-1=-7.15 \%$ & $1.022168-1=2.168 \%$ & $1.02202-1=2.202 \%$ \\
\hline 2 & $1.0253-1=2.53 \%$ & $.9821-1=-1.79 \%$ & $1.02367-1=2.367 \%$ & $1.02331-1=2.331 \%$ \\
\hline 3 & $.9639-1=-3.61 \%$ & $.9731-1=-2.69 \%$ & $1.02316-1=2.136 \%$ & $1.02322-1=2.322 \%$ \\
\hline 4 & $1.0369-1=3.69 \%$ & $.9836-1=-1.64 \%$ & $1.02274-1=2.274 \%$ & $1.02261-1=2.261 \%$ \\
\hline \multicolumn{5}{|c|}{1987} \\
\hline 1 & $1.184-1=18.4 \%$ & $1.05976-1=5.976 \%$ & $1.01921-1=1.921 \%$ & $1.019303-1=1.9303 \%$ \\
\hline 2 & $1.0340-1=3.40 \%$ & $1.10083-1=10.083 \%$ & $1.02159-1=2.159 \%$ & $1.02077-1=2.077 \%$ \\
\hline 3 & $1.0707-1=7.07 \%$ & $1.03299-1=3.299 \%$ & $1.02288-1=2.288 \%$ & $1.02202-1=2.202 \%$ \\
\hline 4 & $.7457-1=-25.43$ & $.9811-1=-1.89 \%$ & $1.02327-1=2.327 \%$ & $1.023567-1=2.3567 \%$ \\
\hline \multicolumn{5}{|c|}{1986} \\
\hline 1 & $1.1742-1=17.42 \%$ & $1.06898-1=6.898 \%$ & $1.02242-1=2.242 \%$ & $1.02364-1=2.364 \%$ \\
\hline 2 & $1.0652-1=6.52 \%$ & $1.08846-1=8.846 \%$ & $1.01999-1=1.999 \%$ & $1.01989-1=1.989 \%$ \\
\hline 3 & $.9733-1=-2.67 \%$ & $1.02325-1=2.325 \%$ & $1.01984-1=1.984 \%$ & $1.01977-1=1.977 \%$ \\
\hline 4 & $1.0672-1=6.72 \%$ & $.9902-1=-.98 \%$ & $1.011928-1=1.9728 \%$ & $1.02005-1=2.005 \%$ \\
\hline \multicolumn{5}{|l|}{1985} \\
\hline 1 & $1.0685-1=6.85 \%$ & $.9799-1=-2.01 \%$ & $1.02883-1=2.883 \%$ & $1.028308-1=2.8308 \%$ \\
\hline 2 & $1.0352-1=3.52 \%$ & $1.0244-1=2.44 \%$ & $1.02752-1=2.752 \%$ & $1.02860-1=2.86 \%$ \\
\hline 3 & $1.0067-1=.679 \%$ & $1.02974-1=2.974 \%$ & $1.026709-1=2.6709 \%$ & $1.0265-1=2.65 \%$ \\
\hline 4 & $1.1533-1=15.33 \%$ & $1.00546-1=.546 \%$ & $1.025412-1=2.5412 \%$ & $1.02607-1=2.607 \%$ \\
\hline \multicolumn{5}{|c|}{1984} \\
\hline 1 & $.8981-1=-10.19 \%$ & $1.018-1=1.80 \%$ & $1.029136-1=2.9136 \%$ & $1.028616-1=2.8616 \%$ \\
\hline 2 & $.9643-1=-3.57 \%$ & $.9524-1=-4.76 \%$ & $1.032046-1=3.2046 \%$ & $1.0313-1=3.13 \%$ \\
\hline 3 & $1.08139-1=8.139 \%$ & $.9537-1=-4.63 \%$ & $1.031163-1=3.1163 \%$ & $1.031596-1=3.1596 \%$ \\
\hline
\end{tabular}




\begin{tabular}{|c|c|c|c|c|}
\hline 4 & $.9879-1=-1.21 \%$ & $1.03186-1=3.186 \%$ & $1.028704-1=2.8704 \%$ & $1.029376-1=2.9376 \%$ \\
\hline \multicolumn{5}{|l|}{1983} \\
\hline 1 & $1.1030-1=10.306 \%$ & $1.07116-1=7.116 \%$ & $1.026319-1=2.6319 \%$ & $1.026289-1=2.6289 \%$ \\
\hline 2 & $1.07637-1=7.637 \%$ & $1.07692-1=7.692 \%$ & $1.02609-1=2.609 \%$ & $1.025749-1=2.5749 \%$ \\
\hline 3 & $1.0186-1=1.86 \%$ & $1.03488-1=3.0488 \%$ & $1.028414-1=2.8414 \%$ & $1.027948-1=2.7948 \%$ \\
\hline 4 & $1.02058-1=2.058 \%$ & $1.02352-1=2.352 \%$ & $1.028575-1=2.8575 \%$ & $1.028441-1=2.8441 \%$ \\
\hline \multicolumn{5}{|c|}{1982} \\
\hline 1 & $.9335-1=-6.65 \%$ & $.9249-1=-7.50 \%$ & $1.033998-1=3.3998 \%$ & $1.032427-1=3.2427 \%$ \\
\hline 2 & $.9791-1=-2.08 \%$ & $.9820-1=-1.80$ & $1.032740-1=3.247 \%$ & $1.032373-1=3.2373 \%$ \\
\hline 3 & $1.1463-1=14.63 \%$ & $1.1104-1=11.04 \%$ & $1.030817-1=3.0817 \%$ & $1.032042-1=3.2042 \%$ \\
\hline 4 & $1.1442-1=14.42 \%$ & $1.14988-1=14.988 \%$ & $1.02607-1=2.607 \%$ & $1.0271-1=2.710 \%$ \\
\hline \multicolumn{5}{|l|}{1981} \\
\hline 1 & $1.0309-1=3.09 \%$ & $.9960-1=-.4 \%$ & $1.030329-1=3.0329 \%$ & $1.029945-1=2.9945 \%$ \\
\hline 2 & $1.0015-1=.155 \%$ & $1.011656-1=1.1656 \%$ & $1.031985-1=3.1985 \%$ & $1.03185-1=3.158 \%$ \\
\hline 3 & $.8430-1=-15.7 \%$ & $.9901-1=-.99 \%$ & $1.034376-1=3.4376 \%$ & $1.03303-1=3.3036 \%$ \\
\hline 4 & $1.0369-1=3.69 \%$ & $.9862-1=-1.38 \%$ & $1.033363-1=3.3363 \%$ & $1.03397-1=3.397 \%$ \\
\hline \multicolumn{5}{|c|}{1980} \\
\hline 1 & $.9325-1=-6.75$ & $1.02035-1=2.035 \%$ & $1.028134-1=2.8134 \%$ & $1.026296-1=2.6296 \%$ \\
\hline 2 & $1.0639-1=6.39 \%$ & $.9820-1=-1.80 \%$ & $1.02525-1=2.525 \%$ & $1.027037-1=2.7037 \%$ \\
\hline 3 & $1.0860-1=8.6 \%$ & $1.02959-1=2.959 \%$ & $1.026311-1=2.6311 \%$ & $1.02506-1=2.5606 \%$ \\
\hline 4 & $.9853-1=-1.47 \%$ & $1.00719-1=.719 \%$ & $1.02938-1=2.938 \%$ & $1.028466-1=2.8466 \%$ \\
\hline \multicolumn{5}{|c|}{1979} \\
\hline 1 & $1.0320-1=3.20$ & $1.0088-1=.88 \%$ & $1.02124-1=2.124 \%$ & $1.021103-1=2.1105 \%$ \\
\hline 2 & $.9679-1=-3.21 \%$ & $1.00626-1=.626 \%$ & $1.021239-1=2.1239 \%$ & $1.021327-1=2.1327 \%$ \\
\hline 3 & $1.0286-1=2.86$ & $1.01329-1=1.329 \%$ & $1.021358-1=2.1358 \%$ & $1.02105-1=2.1051 \%$ \\
\hline 4 & $.9396-1=-6.04 \%$ & $.9874-1=-1.26 \%$ & $1.024209-1=2.4209 \%$ & $1.023429-1=2.3429 \%$ \\
\hline
\end{tabular}

Notes: 1) Quarterly compounded returns are estimated on a monthly basis as follows: $\left[\left(1+R_{M 1}\right)\left(1+R_{M 2}\right)\left(1+R_{M 3}\right)\right]-1 . R_{M 1}, \ldots, R_{M 3}$ are returns for the first to the third month for a specific quarter. We subtract 1 to get a rate of return.

2) Bold shows the market with the highest forecasted quarterly compound returns. Our portfolio is constructed based on the highest forecast we get from the forecasting model. Accordingly we switch our portfolio to the market with higher forecasted returns .

\section{COMPARISON OF QUARTERLY COMPOUNDED RETURNS FOR DOW JONES INDUSTRIAL AVERAGE AND OUR PORTFOLIO.}

\begin{tabular}{|c|c|c|c|c|c|}
\hline Year-qrt 1997 & Dji:actual & Portfolio: Actual & Year-qtr 1994 & Dji:actual & Portfolio: actual \\
\hline 1 & $1.6 \%$ & $1.6 \%$ & 1 & $14.17 \%$ & $1.4 \%$ \\
\hline 2 & $16.9 \%$ & $16.9 \%$ & 2 & $-.16 \%$ & $1.73 \%$ \\
\hline 3 & $3.3 \%$ & $3.3 \%$ & 3 & $5.82 \%$ & $1.8 \%$ \\
\hline 4 & $-.12 \%$ & $1.5 \%$ & 4 & $.19 \%$ & $1.97 \%$ \\
\hline 1996 & & & 1993 & & \\
\hline 1 & $8.67 \%$ & $8.67 \%$ & 1 & $4.22 \%$ & $1.58 \%$ \\
\hline 2 & $1.16 \%$ & $1.16 \%$ & 2 & $1.91 \%$ & $1.91 \%$ \\
\hline 3 & $3.83 \%$ & $1.71 \%$ & 3 & $1.3 \%$ & $1.3 \%$ \\
\hline 4 & $9.6 \%$ & $1.5 \%$ & 4 & $5.86 \%$ & $5.86 \%$ \\
\hline \multicolumn{6}{|l|}{1995} \\
\hline 1 & $7.87 \%$ & $1.8 \%$ & & & \\
\hline 2 & $9.54 \%$ & $1.6 \%$ & & & \\
\hline
\end{tabular}




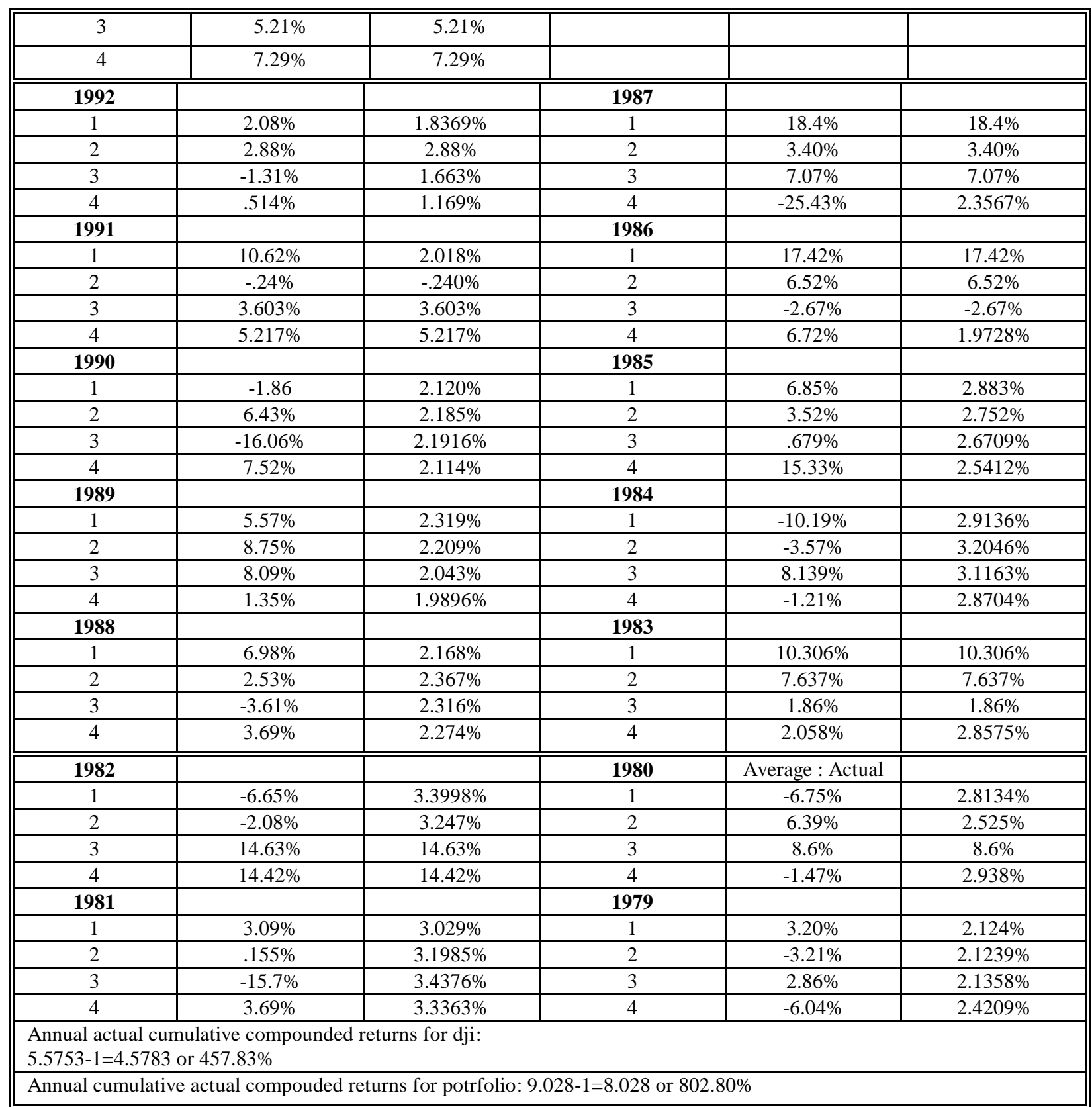

Notes: 1) We compare actual cumulative compounded returns on the Dow Jones Industrial Average with the returns of our portfolio. As can be seen by the end of 1992 our portfolio has generated compounded returns of $744.75 \%$ versus $242.83 \%$ of the DJI.

TABLE V

SWITCING PORTFOLIO: BONDS AND STOCKS

\begin{tabular}{||c|c|c|c|c|c|c|c|c|c||}
\hline \hline & YEAR & & & & & & & & \\
\hline QTR & 1997 & 1996 & 1995 & 1994 & 1993 & 1992 & 1991 & 1990 & 1989 \\
\hline 1 & S & S & B & B & B & B & B & B & B \\
\hline
\end{tabular}




\begin{tabular}{|c|c|c|c|c|c|c|c|c|c|}
\hline 2 & $\mathrm{~S}$ & $\overline{\mathrm{S}}$ & B & $\overline{\mathrm{S}}$ & $\overline{\mathrm{S}}$ & $\mathrm{S}$ & $\overline{\mathrm{S}}$ & B & B \\
\hline 3 & $S$ & B & $S$ & $S$ & $\mathrm{~S}$ & B & $\mathrm{S}$ & B & B \\
\hline \multirow[t]{2}{*}{4} & B & B & $S$ & $\mathrm{~S}$ & $\mathrm{~S}$ & B & $\mathrm{S}$ & B & B \\
\hline & 1988 & 1987 & 1986 & 1985 & 1984 & 1983 & 1982 & 1981 & 1980 \\
\hline 1 & B & $\mathrm{S}$ & & B & B & $\mathrm{S}$ & B & B & B \\
\hline 2 & B & $\mathrm{S}$ & $S$ & B & B & $\mathrm{S}$ & B & B & B \\
\hline 3 & B & $S$ & $\mathrm{~S}$ & $S$ & B & $\mathrm{S}$ & $\mathrm{S}$ & B & B \\
\hline \multirow[t]{2}{*}{4} & B & B & B & B & $\mathrm{S}$ & B & $\mathrm{S}$ & B & B \\
\hline & 1979 & & & & & & & & \\
\hline 1 & $\mathrm{~B}$ & & & & & & & & \\
\hline 2 & B & & & & & & & & \\
\hline 3 & B & & & & & & & & \\
\hline 4 & B & & & & & & & & \\
\hline
\end{tabular}

Notes: The table presents our switching portfolio which is comprised of bonds (B) and stocks (B).

\section{REFERENCES}

1. Andrianacos D. (1989). "The domestic term structure of interest rates and their international linkages: An empirical study." Unpublished Ph.D. Thesis, University of Illinois at Chicago (1989).

2. Bessembinder Hendrik and Kalok Chan, Department of Finance College of Business Arizona State University: Working Paper, Draft of March, 1995. 1995

3. $\quad$ Campbell J., (1987). "Stock returns and the Term Structure", Journal of Financial Economics, 18 (1987): $373-379$.

4. Campbell J.Y. and J. Ammer (1993). "What Moves the Stock and Bond Markets? A Variance Decomposition for Long-Term Asset Returns." The Journal of Finance, vol. xlviii no.1 (March 1993):3-37.

5. Campbell J. and R. Shiller. "The Dividend-Price ratio and Expectations of Future Dividends and Discount Factors", The Review of Financial Studies 1:195-228.

6. Campbell, Y. John and Robert Shiller. "Stock Prices, Earnings, and Expected dividends". The Journal of Finance, Vol. xliii, No.3, July (1988b).

7. Conrad J. and G. Kaul (1995). "An Anatomy of Trading Strategies." Working paper

8. Cootner, Paul H.,(1964). The Random Character of Stock Market Prices, Cambridge: MIT Press.

9. Denis J. D., D. K. Denis and A. Sarin (1994). "The Information Content of Dividend Changes: Cash Flow Signaling, Overinvestment, and Dividend Clienteles". Journal of Financial and Quantitative Analysis, vol. 29, no.4, (December 1994).

10. DeBondt, Werner, and Richard Thaler (1985). "Does the Stock Market Overreact?" Journal of Finance 40:793-805.

11. Dickey, David A. and Wayne A. Fuller (1979). "Distribution of the Estimators for Autoregressive Time Series with a Unit Root." Journal of the American Statistical Association, June 1979 Vol.74, No.366.

12. Dickey, David A. and Wayne A. Fuller. "Likelihood ratio statistics and autoregressive time series with a unit root." Econometrica 49:1057-1072., (1981).

13. Fama, Eugene F. (1965). "The behavior of Stock Market Prices". Journal of Business, 38:34-105 (1965).

14. Fama, Eugene F.(1970). "Efficient Capital Markets: A Review of Theory and Empirical Work." Journal of Finance 25 (May 1970):383-417.

15. Fama, E. F. "Short term interest rates as predictors of inflation." American Economic Review 65, (1975):269-282.

16. Fama, E. F. (1991). "Efficient Capital Markets: II." Journal of Finance 46:5:1575-1618.

17. Fama F. Eugene and Kenneth R. French. Dividends Yields and Expected Stock Returns", Journal of Financial Economics 22 (1988) 3-25.

18. Fama E. F., and R. Bliss (1987), "The information in long- maturity forward rates". American Economic Review 77 , (1987):680-692.

19. Fama F. Eugene and Kenneth R. French. "Permanent and Temporary Components of Stock Prices". Journal of 
Political Economy, (1988), Vol.96, No.2.

20. Fama F. Eugene (1990a). "Stock returns, expected returns and real activity", Journal of Finance, 45:1089-1108 (1990a).

21. Fama F. Eugene and William Schwert, (1977). "Asset returns and inflation", Journal of Financial Economics, 5 :115-146 (1977).

22. Frankel A.G., and C.S. Lown (1994) "An indicator of future inflation extracted from the steepness of the interest rate yield curve along its entire length". _Quarterly Journal of Economics (May 1994):518-530.

23. French, Kenneth R., and Richard Roll (1986). Stock Return Variances: The Arrival of Information and the Reaction of Traders," Journal of Financial Economics 17: 5-26.

24. Hiemstra C. and J.D. Jones (1994). "Testing for Linear and Nonlinear Granger causality in the Stock Price-Volume Relation." The Journal of Finance, vol. xlix, no.5 (December 1994):1639-1664.

25. Goetzman W. N. and Jorion P. "Testing the Predictive Power of Dividend Yields", Journal of Finance 48, no.2, (June 1993).

26. Granger C.W.J. and P. Newbold, Forecasting Economic Time Series, Academic Press, New York, 1977.

27. Gray Philip K. and Gray Stephen F., "Testing Market Efficiency: Evidence From The NFL Betting Market", The Journal of Finance, 1997.

28. Jegadeesh N. and S. Titman (1993). "Returns to Buying Winners and Selling Loosers: implications for Stock Market Efficiency." The Journal of Finance vol. xlviii, no.1 (March 1993):65-93.

29. Kandel Shmuel and Stambaugh Robert F. "On the Predictabiltiy of Stock Returns: An Asset Allocation Perspective", Journal of Finance_, Vol. Li, No. 2 June 1996

30. The Wharton School University of Pennsylvania.

31. Keim D.B. and R.F.Stambaugh. "Predicting Returns in Stock and Bonds Markets." Journal of Financial Economics 17, (1986): 357-390.

32. Lo Andrew, (1991). "Long-term memory in stock prices". Econometrica (September 1991), 1279-1314.

33. Lo A., and A. G. MacKinlay (1990). "When are contrarian profits due to stock market overreaction?" Review of Financial Studies 3: 175-205.

34. Lo A., and A. G. MacKinlay. "Stock market prices do not follow random walks: Evidence of simple specification tests." The Review of Financial Studies 1, no.1 (Spring 1988):41-66.

35. Malkiel G. Burton. "Expectations, Bond Prices, and the Term Structure of Interest Rates". Quarterly Journal of Economics

36. Mankwi, N. G. (1986). "The term structure of interest rates revisited" Brookings Papers on Economic Activity. 1:5788, 1986.

37. Mishkin F. "Are Market Forecasts Rational?" American Economic Review 71 (1981b):293-306

38. Mishkin, F. (1991). "A multicountry study of the information in the term-structure about future inflation," Journal of International Money and Finance, xix (1991): 2-22.

39. Mishkin, F. (1992). "Yield curve," New Palgrave Dictionary of Money and Finance (New York, NY: Stocton Press, 1992).

40. Nelson C.R. and M.Kim (1993). "Predictable Stock Returns: The role of the Small Sample Bias." The Journal of Finance, 48:641-661.

41. Pierce David A. and Larry D. Haugh (1977), "Causality in Temporary Systems". Journal of Econometrics 5, (1977): 265-293.

42. Phillips P.C.B.. "Time regressing with a unit root", Econometrica55:277-301 (1987).

43. Potterba J.M.and Summers L.H. "Mean Reversion in Stock Prices Evidence and Implications." Journal of Financial Economics 22 (1988).

44. Reichenstein W. and S. P. Rich (1994). "Predicting Long-Horizon Stock Returns: Evidence and Implications." Financial Analysts Journal (January/February 1994):73-76.

45. $\quad$ Rozeff S. M. (1984). "Dividend yields are equity risk premiums." Financial Analysts Journal, (Fall 1984):68-75.

46. Said, S. E. and Dickey, D.A. "Testing for unit roots in autoregressive moving average models of unknown order", Biometrica 71: 599-608, (1985).

47. Shiller, Robert J. (1979). "The Volatility of Long-Term Interest Rates and Expectations Models of the Term Structure". Journal of Political Economy 87: 1190-1219.

48. Shiller J. Robert (1981). "The Use of Volatility Measures in Assessing Market Efficiency". The Journal of Finance Vol. xxxvi, No.2, May (1981).

49. $\quad$ Shiller, J. Robert (1981a). "Do Stock Prices Move too Much to be Justified by Subsequent Changes in Dividends?" American Economic Review 71: 421-436. 
50. Shiller R. "Market Volatility and Investor Behavior". The American Economic Review, vol.80, no.2 (May 1990):5868.

51. Summers H. Lawrence.: "Does The Stock Market Rationally Reflect Fundamental Values?" The Journal of Finance, Vol. xli, No.3, July 1986. 